\title{
RESISTANCE OF Escherichia coli FROM RECTAL SWAB CULTURE IN HEMATO-ONCOLOGY WARDS, DR. SOETOMO HOSPITAL, SURABAYA
}

\author{
Rahmi Rusanti, IGAA Putri Sri Rejeki \\ Department of Clinical Pathology, Faculty of Medicine, \\ Universitas Airlangga, Surabaya
}

\begin{abstract}
ABSTRAK
Pasien dengan keganasan hematologi yang dirawat di rumah sakit memiliki risiko sangat besar terjangkit infeksi. Mikroorganisme penyebab infeksi bisa bersifat endogen, yaitu berasal dari dalam tubuh pasien. Sebagian besar penyebab infeksi berasal dari koloni bakteri yang terdapat dalam usus. Escherichia coli adalah bakteri fakultatif anaerob, berbentuk batang, bersifat gram negatif, dan merupakan flora normal usus. E. coli juga merupakan bakteri yang paling sering menyebabkan infeksi nosokomial. Resistensi E. coli terhadap berbagai antibiotika telah banyak dilaporkan.Tujuan dari penelitian ini adalah untuk mengetahui perkembangan sifat resistensi Escherichia coli yang diperoleh dari kultur usap rektum pasien keganasan hematologi anak. Pengamatan data sekunder hasil tes kepekaan antibiotika dari kultur usap rektum yang terdapat pertumbuhan Escherichia coli,yang dilaksanakan di ruang rawat inap hematologi-onkologi anak RS Dr. Soetomo Surabaya selama bulan Oktober 2012-Maret 2013. Terdapat 20 hasil tes kepekaan antibiotikadari kultur usap rektum yang terdapat pertumbuhan Escherichia coli. Resistensi tertinggi ditunjukkan terhadap golongan antibiotika kotrimoksazol, ampisilin sulbaktam dan sefotaksim. Ditemukan juga Escherichia coli dengan sifat extendedspectrum $\beta$-lactamase(ESBL). Escherichia coli pada kultur usap rektum pasien keganasan hematologi anak memiliki resistensi terhadap kotrimoksazol, ampisilin, sulbaktam dan ampisilin.(FMI 2015;51:193-195)
\end{abstract}

Kata kunci: Escherichia coli, resistensi, antibiotika.

\begin{abstract}
Malignant hematology patients in the hospital are particularly susceptible to infection associated with endogenous microorganism originating from their own body. The most common etiology of infection is bacteria from gastrointestinal tract. Escherichia coli is a gram-negative facultative anaerobic bacteria, and part of the intestinal normal flora. However, E. coli is the most common cause of nosocomial infection. Resistance of E. coli to antibiotics has been widely reported. The aim of this study was to identify the development of antibiotic resistant properties of Escherichia coli from rectal swab of malignant hematology pediatric patients. A descriptive study of collected secondary data on sensitivity test results was done in the hematology-oncology pediatric ward, Dr. Soetomo Hospital from October 2012 to March 2013. There were 20 results of antibiotic susceptibility testing on positive Escherichia coli cultures from rectal swabs. The highest resistance levels were found towards cotrimoxazol, ampicillin sulbactam and cefotaxime. Escherichia coli with extended-spectrum $\beta$-lactamase (ESBL) was also found. Escherichia coli from rectal swabs of malignant hematology pediatric patients were shown to be resistant to cotrimoxazol, ampicillin sulbactam and ampicillin.(FMI 2015;51:193-195)
\end{abstract}

Keywords: Escherichia coli, resistance, antibiotics.

Correspondence: Rahmi Rusanti, Department of Clinical Pathology, Faculty of Medicine, Universitas Airlangga, Jalan Prof. Dr. Moestopo 47, Surabaya 60131, Indonesia. Email: rahmirusanti@yahoo.co.id

\section{INTRODUCTION}

The resistance of $E$. coli to various antibiotics has been widely reported. Escherichia coli is a rod-shaped gramnegative bacteria in single cells or in pairs, the normal intestinal flora that contributes to the normal function of intestine and nutrients, but will be pathogenic bacteria when it reaches the tissue outside intestinal tissue. Hospitalized patients with hematologic malignancies had a great risk for an infection, even life-threatening sepsis. The microorganisms that cause the infection may be endogenous, deriving from the patient's body, or from the transmission of infection of other patients who are also being treated in the hospital. Most of the causes of infection are derived from bacterial colonies found in the intestine, which can ultimately lead to severe sepsis or death (Rena et al 2010).

Clinical manifestations of $E$. coli infection depend on the area of infection and cannot be distinguished from symptoms caused by the other bacteria (Holt et al 1994, Forbes et al 2006). The presence of different patterns of bacteria in each respective environment makes it more difficult to give empiric antibiotics. By collecting data about microbials pattern that corresponds to the surrounding environment is a way to reduce the occur- 
rence of infections in patients with hematologic malignancies, and simultaneously suppress the incidence of bacteria resistance to the pre-existing antibiotic (Nilsson et al 2003). The purpose of this study was to determine the development of resistance of the Escherichia coli obtained from rectal swab cultures of patients with pediatric hematologic malignancies in Pediatric Hemato-Oncology Ward, Dr. Soetomo Hospital Surabaya.

\section{MATERIALS AND METHODS}

This research was a descriptive study of the secondary data held in the pediatric hematology-oncology ward in Dr. Soetomo Hospital Surabaya. The population was patients who had been treated in Pediatric HematoOncology ward and had antibiotic sensitivity test results from rectal swab culture. The sample was patients who had antibiotic sensitivity test results from the rectal swab culture containing the growth of Escherichia coli in the ward during the period of October 2012 - March 2013. Exclusion criteria were patients who have rectal swab cultures containing the growth of Escherichia coli but do not have the sensitivity test results, incomplete and illegible medical records, or unclear and illegible susceptibility test results.

\section{RESULTS}

Data were obtained from medical records and patient registration data of pediatric hematology-oncology ward patients who had antibiotic sensitivity test results from rectal swab cultures containing the growth of Escherichia coli in October 2012 - March 2013, as many as 20 subjects.

Table 1. Escherichia coli resistance to antibiotics

\begin{tabular}{lc}
\hline \multicolumn{1}{c}{ Antibiotics } & Frequention (\%) \\
\hline First line drugs & \\
Ampicillin & $12(60)$ \\
Gentamicin & $7(35)$ \\
Tobramycin & $1(5)$ \\
Second line drugs & \\
Amykacin & $0(0)$ \\
Amoxyicilin Clavulanat Acid & $9(45)$ \\
Ampicillin Sulbactam & $13(65)$ \\
Piperasilin Tazobactam & $3(15)$ \\
Clavulanat Tikarsilin Acid & $4(20)$ \\
Cefotaxime & $8(40)$ \\
Ceftriaxone & $9(45)$ \\
Meropenem & $1(5)$ \\
Cotrimoxazole & $16(80)$ \\
\hline
\end{tabular}

Antibiotic resistance test results of the rectal swab culture containing the growth of Escherichia coli showed the highest resistance to cotrimoxazole (80\%). (Table 1). Four Escherichia coli cultures were found with ESBL (extended-spectrum $\beta$-lactamase). The results of this study showed that ESBL E. coli was sensitive to antibiotics meropenem (100\%).

Table 2. Antibiotic sensitivity of E.coli ESBL ( $n=4)$

\begin{tabular}{lc}
\hline \multicolumn{1}{c}{ Antibiotics } & Frequency $(\%)$ \\
\hline First line drugs & \\
Ampicillin & $0(0)$ \\
Gentamicin & $2(20)$ \\
Tobramycin & $1(25)$ \\
Second line drugs & \\
Amykacin & $3(75)$ \\
Amoxyicilin Clavulanat Acid & $0(0)$ \\
Ampicillin Sulbactam & $1(25)$ \\
Piperasilin Tazobactam & $1(25)$ \\
Clavulanat Tikarsilin Acid & $0(0)$ \\
Cefotaxime & $0(0)$ \\
Ceftriaxone & $0(0)$ \\
Meropenem & $4(100)$ \\
Cotrimoxazole & $0(0)$ \\
\hline
\end{tabular}

\section{DISCUSSION}

E. coli is a normal flora in human gastrointestinal tract. Although being a normal flora, which is safe and does not cause health problems, E. coli can still cause some problems in patients with decreased immunity, due to malignancy of the disease itself or due to sitostatics that lead the patient more susceptible to infection, which is known as immunocompromised. This situation may result in the patient becomes infected by microorganisms either from his own body or from outside.

The results of this study showed a high resistance of $E$. coli obtained from rectal swab cultures of pediatric patients with hematologic malignancies. This study reported that E. coli, a normal flora of the gastrointestinal tract, turned out to have resistance to cotrimoxazole, ampicillin sulbactam, and $\beta$-lactam class Ampicillin. Antibiotics should be used with caution because $E$. coli has mechanism of resistance on genes of extended-spectrum $\beta$-lactamase (ESBL). It is consistent with the results obtained in this study, that there were four cultures showing Escherichia coli with ESBL properties.

\section{CONCLUSION}

Escherichia coli in rectal swab culture of hematological malignancies in pediatric patients have resistance to cotrimoxazole, ampicillin, sulbactam and ampicillin. 


\section{REFERENCES}

Forbes BA, Sahm DF, Weissfeld AS (2006). Bailey \& Scott's Diagnostic Microbiology, 12th ed., Philadelphia, Elsevier, 323-333

Holt GJ, Krieg RN, Sneath HAP, Staley HAP,Williams TS. Enterobacteriaceae (1994). Bergey's Manual of Determinative Bacteriology, 9th ed., Maryland, Williams \& Wilkins, p 179-180
Nilsson AI, Berg OG, Aspevall O, Kahlmeter G, Andersson DI (2003). Biological costs and mechanisms of fosfomycin resistance in Escherichia coli. Antimicrob Agents Chemother 47, 2850-2858

Rena RA, Suega K, Bakta IM (2010). Pola kepekaan bakteri pada pasien keganasan hematologi di RSUP Sanglah Denpasar. Journal of Internal Medicine 11, 104-109 